\title{
THE POTENTIAL FOR MARINE ECOTOURISM IN MUKIM TANJUNG KUPANG, JOHOR, MALAYSIA THROUGH CAPACITY BUILDING OF LOCAL COMMUNITIES VIA ENVIRONMENTAL EDUCATION
}

\author{
Serina Rahman* \& Harinder Rai Singh \\ *first author \\ Universiti Teknologi MARA, Malaysia \\ (serina_mola@yahoo.com, harinderrai.singh@gmail.com) \\ DOI: https://doi.org/10.22452/samudera.vol1no1.5
}

\begin{abstract}
Marine tourism is a growing industry in Malaysia, with most tourism infrastructure and development focused on famous islands and sandy beaches. Less well-known areas on the south-west coast of the Peninsular such as Sungai Pulai that feature coastal mangroves and seagrass meadows are unfortunately not given emphasis. This paper outlines the potential of the mangrove and seagrass habitats of Sungai Pulai for marine tourism as well as its possible impacts (positive and negative) on its local communities. It is essential that local communities within the tourism realm are actively involved and have a say in tourism development and that they stand to benefit economically. This paper uses the example of Mukim Tg Kupang, Johor as an area that has marine tourism potential, even though it does not fall into the 'typical' expectation of sandy beaches and beautiful dive sites. Strategies to ensure local community participation and benefits include environmental awareness through education and enhancing communication skills of the locals in their efforts to preserve their marine habitat. A holistic approach to marine tourism via the understanding of their physical and biological environment as well as intellectual and aesthetic development creates the capacity to enhance marine conservation.
\end{abstract}

Keywords: Local communities, environmental education, conservation, marine, tourism management

\section{Introduction}

Marine tourism is a growing industry in the world, not least in Malaysia. However, much of local marine tourism focuses on islands and white sand beaches. Mangroves and seagrass meadows are intrinsically marine environments, yet ecotourism to these areas is in its infancy. The Sungai Pulai estuary harbours both these ecosystems, yet tourism here revolves mainly around recreational fishing and the purchase and consumption of seafood. This paper and the research project that highlights hopes to show that locally-led, small-scale marine tourism in this area is possible and that environmental education is the key to making it work. Should the program succeed, the local community may be reassured and motivated to move 
towards new sources of income and gain continued economic benefit from the preservation (instead of exploitation) of their natural resources.

\section{Definition of Marine Tourism}

Tourism has many forms ranging from mass to alternative or specific interest in tourism. 'Ecotourism' is a popular tourism term where the main features should include low-impact sustainable use and management of natural resources leading to conservation, environmental education for both the visitor and the host community; as well as local community participation, employment opportunities, economic benefit, cultural revival and empowerment (Jacobson \& Robles, 1992; Kibicho, 2008; Newsome, Moore \& Dowling, 2006; Pipinos \& Fokiali, 2007).

Nature-based tourism falls within this category, but focuses on tourism in natural settings, allowing for an emphasis on understanding the natural environment (Newsome, Moore \& Dowling, 2006). Marine tourism narrows the field even further, specifying some interaction with the marine environment. This could broadly include foreshore, offshore and coastal marine areas, land-based marine activities such as shore angling, as well as cultural and heritage aspects of coastal regions and communities (Wilson \& Garrod, 2003).

\section{Malaysian Marine Tourism}

Between 2000 and 2009, visitor arrivals at Marine Parks have shown a steady increase with the period between 2008-2009 recording 530,000 visitors (Marine Park Department, n.d.). This is the figure for only registered visitors to Marine Parks in Peninsular Malaysia. There are many more visitors who visit beaches and islands that are not gazetted Marine Parks as well as marine destinations in Sarawak and Sabah. Overall visitor numbers to Malaysia have increased every year, logging 23.6 million people in 2009 (Tourism Malaysia, n.d.).

Typical marine tourism activities often include the observation of megafauna such as whales, dolphins, fish, scuba diving, snorkelling, beach walking, rock pooling, recreational boating, recreational fishing and yachting (Wilson \& Garrod, 2003). Promotional images of these activities often feature idyllic white-sand beaches and crystalline seas of pristine coastlines and remote islands. A case in point is the marketing of marine tourism in Malaysia. The main Tourism Malaysia website has a feature on Pulau Redang on its home page; special advertorials for islands and beaches; and a dedicated destination section for "Island Life". The copy often uses terminology such as "the most beautiful beaches in the world... crystal clear waters... thrilling water sports... mesmerizing reefs" (Tourism Malaysia, n.d.) The most touted destinations include Langkawi, Pulau Tioman, Pulau Redang, Sipadan and other dive-centric locations in Sabah.

It is interesting to note that while mangroves and seagrass areas are undoubtedly part of the marine ecosystem, they are not heavily promoted as a marine tourism destination. Instead, they are featured based on other physical aspects, such as "the southern-most point of continental Asia" (for Tanjung Piai Johor National Park) (Tourism Malaysia, n.d) or related Non-Governmental Organisations (NGOs) such as Wetlands International (Wetlands International, n.d.). 


\section{Sungai Pulai Estuary}

The Sg Pulai estuary lies at the mouth of the river that feeds the Sg Pulai Mangrove Forest Reserve, a gazetted RAMSAR site; an internationally recognised wetlands area. It is the most extensive riverine mangrove system in Johor state and encompasses seagrass meadows, intertidal mudflats and coastal as well as inland riverine mangrove forests (RAMSAR, n.d.). Within this protected forest, three species of mangrove plants are recorded as notably uncommon: Avicennia lanata (an endemic species), Brugeira sexangulata and Podocarpus polystachus. Fauna of conservation value includes the Mangrove Pitta, the Lesser Mouse Deer, the Slow Loris, the Leopard Cat, the Bearded Pig and the Estuarine Crocodile (Choo, Rahman \& Khor, 2009).

Three seagrass meadows lie at the mouth of the Sg Pulai River. The largest of these, Beting Tanjung Kupang (also referred to as the Merambong Shoals) is $1.8 \mathrm{~km}$ long and is believed to be Peninsular Malaysia's largest contiguous seagrass meadow (Choo et al., 2009). The other two seagrass areas, Pantai Tanjung Kupang and Beting Tanjung Adang are slightly smaller, yet the area as a whole is known to have nine species of seagrass, the highest species diversity on record for Malaysia (Japar, Zakaria, Arshad, 2006). The area is known to host fauna such as the dugong, seahorse (Hippocampus kuda), Smooth Otter and the Hawksbill turtle (Choo et al., 2009; Japar et al., 2006). Recent research has shown that the seagrass meadows have a moderate benthic faunal density and diversity; with Beting Tanjung Adang having the highest mean total density of meiobenthos, and Beting Tanjung Kupang having the highest density of macrobenthic fauna (Zaleha, Farah Diyana, Amira Suhaili \& Amirudin, 2009). The seagrass and mangrove habitats also support a healthy fisheries community: between 70-76 species of fish in 41 families (Sasekumar, Leh, Chong, Rebecca \& Audery, 1989). A recent study by Nurul Amin (Nurul Amin, Arshad, Ara, Daud \& Mazlan, 2009) found 2800 fish larvae belonging to 24 families with a mean abundance of 79 individuals per $100 \mathrm{~m}^{3}$.

As bountiful and valuable as this area is, it does not fall into the regular postcard image of a marine tourism destination. There are no soft white sand beaches, and the water is not suitable for snorkelling or diving.

\section{Other Mangrove and Seagrass Ecotourism Destinations}

Pulau Kukup is an uninhabited mangrove island and an Important Bird Area (IBA) for Malaysia. Just an hour's drive away from the Sungai Pulai area, it hosts the Lesser Adjutant (Leptoptilos javanicus) during its migration and breeding season (RAMSAR, n.d.) Recognised as a RAMSAR site, the island is now gazetted as a state park and is promoted as an ecotourism destination and research site (Wetlands International, n.d.).

Also recognised as a RAMSAR site, Tanjung Piai National Park can be seen from Sungai Pulai estuary and is the southernmost tip of continental Asia. Also gazetted as a state park, it hosts several vulnerable species such as the Pigtailed Macaque, the Mangrove Whistler and the Scaly Anteater (RAMSAR, n.d.). The area is home to about 20 real mangrove species and nine mangrove associate 
species; a high species diversity for an area of its size. The adjacent mudflats are also feeding grounds for five species of large waterbirds and seven species of shorebirds (Wetlands International, n.d). Ecotourism is the lifeline of Tanjung Piai National Park, and a boardwalk through the mangroves replete with interpretive material, lookout towers, exhibition areas and a campsite are available for the nature tourist.

Pulau Tinggi, coupled with Pulau Sibu in eastern Johor is part of a gazetted Marine Park. The islands are known to have six and four species of seagrass respectively and are known feeding grounds for dugongs and turtles (Japar et al., 2006). The islands are popular holiday destinations for local tourists (especially Pulau Tinggi) and Singaporeans (especially Pulau Sibu). Pulau Tinggi has the third-highest seagrass diversity in Peninsular Malaysia and has been the site of numerous university scientific studies, but there does not seem to be any promotion of the ecosystem on the numerous hotel, chalet or tourism websites of the islands. The islands' dive shops instead promote their beaches, coral reefs and coral reef fish (Sea Gypsy Village Resort \& Dive Base Official Website, n.d.; Coconut Village Resort, n.d.).

The above sites are all within the state of Johor. While the mangrove locations are already being promoted as ecotourism destinations, there is a minimal promotion of Pulau Tinggi and Pulau Sibu's rich seagrass ecosystem. It can be seen then that it is possible to promote Sungai Pulai's rich mangrove ecosystem as an ecotourism site in its own right and nature tourism to the seagrass meadows of the Sungai Pulai estuary is a new and unique offering that can be explored.

\section{Mukim Tanjung Kupang}

Mukim Tanjung Kupang comprises nine fishing villages that lie along the southwestern coast of Johor. The local population is mostly Malay fishermen who depend on the nearby Sungai Pulai estuary and its surrounds for their daily catch. Some supplement their catch with produce from modest vegetable farms in their backyards. Many fish in the inshore waters of the coastal mangroves and around the seagrass meadows. Others collect bivalves and snails in the seagrass and mudflats during the low tide. While fish, prawns and crabs are sold to the seafood markets at the jetties, the bivalves and snails are often kept for personal or extended family consumption.

With increased development in the vicinity over the past ten years, local marine habitats have shown evidence of deterioration and a decrease in fish catch and diversity. The displacement of local communities has also contributed to their increased difficulty in sustaining traditional sources of sustenance and income.

\section{Existing Tourism Activities: Recreational Fishing \& Seafood}

Marine tourism in Mukim Tanjung Kupang revolves around recreational fishing and the purchase and consumption of seafood. Fishermen from mostly within the South Johor region and Singapore visit the area to fish either under the Second Link Bridge connecting Singapore to Malaysia or at one of the several fish farms (kelong) offshore. There is an average of about 5-10 anglers per day during the 
week at the Second Link Bridge, and about 20-30 anglers per day during the weekend or during public holidays. Weekday anglers tend to head out alone, while the weekend fishermen tend to fish in groups of 4 friends, rarely bringing partners or families. An average of 20 anglers per week head to one of the 5 kelongs within the Tebrau Straits. The occasional group of fishermen (about 2-3 people) charters a boat and boatman to fish in the Malacca Straits at the mooring site of the container ships about twice a month (Personal communication: Shalan bin Jum'at).

Boat transport is hired from the local community; largely from one family who used to earn a living from fishing themselves but now depend on visitors such as these and other boat charters for an income. On the way to the jetty or their fishing destination, these visitors tend to stop at local shops for light supplies, food and drinks. If their fishing trip is unsuccessful, many stops at a local cage culture (sangkar) - also run by the same family - to buy a fish to bring home.

Other visitors do not fish but head straight to one of three fishmongers that sell the catch of local fishermen. Many of these customers are from Singapore and are known to buy in sizeable quantities, at all times of day and night (depending on the tides and when the fishermen return to shore). Some buy the fish and immediately request to have it cooked at nearby restaurants and food stalls.

While this type of commerce has to do with the marine ecosystem, as part of tourism and contributes to the local economy (part of the ecotourism criteria discussed earlier), there is no educational or environmental awareness component to any of these transactions or activities. It can thus hardly fall into the category of marine nature tourism (Personal communication: Jum'at bin Haron).

\section{Existing Tourism Activities: Natural Areas}

On a local level, villagers and their families occasionally head to Pulau Merambong, an island about 15 minutes offshore to picnic, swim and fish. During school and public holidays, they might bring family and friends from "out of town" to the island as well.

Save Our Seahorses (SOS) is a Malaysian NGO that has been working in the area for several years and conducts monthly public awareness visits to the nearby seagrass meadows. Their clientele are all non-locals; either from other parts of Johor state or from the Klang Valley. Their program has an active environmental education component, sharing with their guest's information on the seagrass ecosystem, its benefits and threats, and development plans for the area. Visitors are then able to experience the seagrass ecosystem and help to look for seahorses and pipefish, which are then tagged by the NGO (Save Our Seahorses Malaysia, n.d.).

While local recreational visits to the nearby island are primarily an encounter with nature, there is no educational component to it. SOS' seagrass experience, on the other hand, is heavily slanted towards public education and awareness and there is some contribution to the local economy as boats are rented locally, but the organisation itself is not local - yet another preferred aspect of genuinely sustainable ecotourism.

At the moment, there does not seem to be any tourism activity that meets all the criteria of sustainable marine tourism. In spite of the existence of rich mangrove forests and seagrass meadows that have substantial ecotourism value, 
they have not yet been used for tourism purposes unlike other locations in Malaysia. It is possible that this came into being because Tanjung Mukim Kupang and its surrounding waters seem an unlikely place for ecotourism; it is flanked on the Malaysian side by a port and the Singaporean side by heavy industry; the waters are more greenish-brown than blue and there are rocky mangrove strewn coasts, not soft beaches. But just as the Lembeh Straits (North Sulawesi, Indonesia) transformed itself from a rubbish-strewn shipping channel to one of the most popular muck diving sites in the world, so can Mukim Tg Kupang and its natural habitats succeed in a unique marine tourism endeavour.

\section{Benefits of Marine Tourism}

Marine Tourism could bring myriad benefits to Mukim Tg Kupang and its surrounds. Given the many existing development plans for the area, genuinely sustainable marine ecotourism is an alternative way for the local community to attain physical development and an improvement in living standards without having to sell off their natural resources or compromise their culture, as well as preserving both nature and culture for the present and future generations. Their participation in marine ecotourism is the best option to achieve sustainable development (Newsome et al., 2006; Wilson \& Garrod, 2001).

Local community involvement in sustainable ecotourism entails smallscale ventures requiring modest capital. Marine tourism offers locals a new form of market-based livelihood, especially given their increased difficulty of sustaining traditional sources of income. Also, there is also less economic leakage, given local participation in tourism ventures. With increased economic stability and revenue derived from the long term preservation of natural resources, there is more reason to avoid resource exploitation (Eagles, McCool \& Haynes, 2002; Mbaiwa \& Stronza, 2010; Nepal, 2004; Walter, 2009; Wilson \& Garrod, 2003).

Given then that the natural habitats are the Golden Goose, there is also increased the incentive to protect and conserve local natural ecosystems. Residents would be aware that any damage to the environment would result in damage to their source of income, and they become obliged to promote conservation. In effect, economic benefits from marine tourism provide the local community with economic incentives to protect their natural resources (Mbaiwa \& Stronza, 2010; Okazaki, 2008; Walter, 2009).

Psychological empowerment, increased self-esteem and self-confidence are some of the intangible benefits of marine tourism. Given visitors' interest in local cultures and heritage, the host community will take pride in their identity as they share their traditions and knowledge with others (Jensen, 2010; Timothy, 2006).

Social empowerment is another result of genuine marine ecotourism. With good capacity-building, an awareness of the environment and the skills to take action and solve problems towards conservation, the local community will be equipped to cooperate and enhance initiatives for long term sustainable development through marine ecotourism. They might even take it upon themselves 
to initiate action to assert their right and autonomy over local natural areas and cultural heritage (Timothy, 2006; Jensen, 2010).

\section{Detrimental Effects of Marine Tourism}

Possible negative impacts to an area due to the influx of tourism include damage to the very environment that people come to see. The presence of too many people in a fragile ecosystem, the advent of increased littering, waste and other recreational pollution in areas with poor existing sanitation and waste treatment could be the death of a delicate natural balance (Diamantis, 2004). The employment of members of the local community could lead to their exploitation if improperly managed; and cultural presentations to visitors could dilute original practices and lead to kitsch, artificial, sometimes completely invented arts performed simply for the benefit of tourists. Alternatively, a loss of traditional cultures and conservative behaviour as a result of the adoption of foreign (i.e. Western) habits, traits, styles of dressing could take place as a result of local exposure to "outsiders" (Diamantis, 2004).

However, if there is real, local community participation in ecotourism and activities carried out in the area are on their terms, on a smaller scale and according to the local community's needs and interests, there is a greater tendency for negative impacts to be avoided or diffused (Kibicho, 2008).

\section{The Key Components of Marine Tourism}

In order to reduce the negative impacts of tourism in a simple, conservative community like Mukim Tanjung Kupang, the central pillars of ecotourism need to be upheld; the minimal impact and use of the natural environment are imperative. The clearing of mangroves and the dredging of estuaries (and therefore, seagrass beds) are common consequences of excessive tourism infrastructure development (Hall, 2001). Thus redeploying existing infrastructure such as jetties and boats will minimise damage to the environment and put less used facilities (due to decreased fishing success) to good economic use (Wilson \& Garrod, 2003).

Keeping tourism small-scale is another key principle of ecotourism (Timothy, 2006) and this too can contribute towards a smaller ecological footprint. Keeping it small also implies keeping it local, thereby maximising local benefits, including employment opportunities and reduced economic leakage (Mbaiwa \& Stronza, 2010; Stem, Lassoie, Lee, Deshler \& Schelhas, 2003; Timothy, 2006).

If all of the above are done well, another key aspect of ecotourism can be attained; empowerment. Discussed in detail in an earlier section, empowerment will then lead back to the continued sustainable use of natural resources and its resources as the local community is then intrinsically motivated and obliged to ensure the preservation of their local natural habitats for their long-term economic benefit (Mbaiwa \& Stronza, 2010).

\section{Environmental Education}

The key to attaining all of the above is environmental education. Environmental education is a process that has the long-term goal of the development of an 
educated citizenry so that they will have the capacity to think critically about biodiversity and other issues pertaining to it (McNeely, 2005). Studies have shown that often, residents do not feel capable or smart enough to participate in tourism. While they might be interested in getting involved in and benefiting from tourism, they might not understand visitors' interest in their location or what these visitors would want to do (Okazaki, 2008).

Local people need to be taught about tourism and its effects as they might not have had the opportunity to be tourists themselves (Timothy, 2006). Considerable public education is required so that the local community can participate in tourism and can actively ensure that tourism development in their mukim is sustainable. Community awareness-building itself leads to empowerment. With increased knowledge and access to the relevant information, they are able to arm themselves against outside influences that might do damage to their natural heritage or cultures (Cole, 2006).

Local community education needs to include both environmental and cultural content, the latter allowing residents to take pride in their cultural traditions and strengthening their identity and self-belief (Cole, 2006; Stem et al., 2003). Environmental education should include the importance of natural resources and how environmental degradation can be minimised (Pipinos \& Fokiali, 2007). An exchange of ideas and relevant training has shown to result in more proenvironmental perspectives than merely economic and employments alone (Stem et al., 2003). This then results in increased environmental sensitivity and empathy towards nature; the bedrock of consequent awareness and the ability to manage a sustainable tourism venture (Wilson \& Garrod, 2003).

Education needs to be as wide as possible and can even include subjects such as local history, foreign languages (i.e. English) - all of which should lead to an adjustment in the local way of thinking so that they can find a balance between development and preservation, thereby attaining sustainable tourism management (Pipinos \& Fokiali, 2007). With increased awareness about more comprehensive tourism, cultural and environmental issues, local participants will be better placed to merge traditional and modern managements and methods to solve problems and manage local resources (Howe, 2001).

\section{Guide Training}

An integral part of local community education is tour guide training. Visitors want an authentic experience when they visit local villages, and a local tour guide is best placed to allow them close contact with the local community (Jensen, 2010). Although such a guide has an advantage over a non-local guide working for a tour operator, training in interpretive techniques and local ecosystem and cultural knowledge can significantly improve visitor satisfaction (Luck, 2003).

Communication skills are an essential component of tour guide training, as the tour guides are the local champions of the local natural habitats (McNeely, 2005). The training program also needs to encompass methods and approaches for passing on the information learnt, so that once the local guides are familiar with the 
content, they will also be capable of disseminating that information to others (Howe, 2001). This ability, in itself leads to empowerment.

As discussed earlier, local community education contributes to many forms of empowerment. Residents trained explicitly as guides, however, attain an acute increase in self-esteem as they share their experiences and knowledge with visitors (Jensen, 2010). Studies have shown that a lack of formal education need not hamper community guides. Armed with their own indigenous or traditional knowledge and bolstered by a good education and awareness program and trained in methods to enlighten others, these guides will develop the motivation to not only to want to continue to learn but to actively seek knowledge from others (Jacobson \& Robles, 1992).

At the same time, their ability to interpret local habitats and cultures for outsiders leads them to develop positive attitudes towards conservation (Christie \& Mason, 2003). This culminates in the sense of stewardship, ownership and responsibility towards their local environments (Howe, 2001).

\section{The Project}

In light of all of the above and as part of a $\mathrm{PhD}$ research project on the use of environmental education for coastal zone management, a group of 46 youth (aged 9-18) from Mukim Tanjung Kupang are being trained as Youth Rangers and guides for their local natural habitats. The program is a holistic one, where the youth are taught about the ecosystems in their vicinity (mangroves, seagrass meadows and rocky shores) and undergo hands-on activities in the actual environment to ensure their familiarity with the habitats. Some of the youth undergo conversational English lessons and those selected as guides receive additional training on aspects of guiding, presentation and communication skills.

Of the 46 youth involved in the project, 18 (all secondary school-aged: 1318 years) are actively involved in seagrass ecosystem education and immersion. The seagrass meadows are accessible only at the lowest tides and the youth visit, monitor and conduct simple experiments in Beting Tanjung Adang once a month. This is coupled with extensive theoretical sessions on seagrass ecology, uses, benefits and threats. Of the 18, nine have so far been selected to brief and guide visitors to the seagrass meadows. These youth were selected based on their ability to speak English, their level of confidence as well as their aptitude with regards to seagrass flora and fauna identification.

Only these older youth are allowed to work at the seagrass meadows due to safety considerations. The youngest of the local youth group involved in the project (aged 8-10 years) are trained as kebun guides (organic farm guides) and show visitors around a small organic farm managed and tended to by the youth themselves. The rest of the youth (aged 10-12 years) are to be trained as mangrove and rocky shore guides, but as the program is still in progress, this last component has not been carried out yet.

In seagrass visits that have already taken place, visitors are taken to the seagrass meadows where they do a simple quadrat analysis guided by local youth guides as a means to familiarise themselves with the habitat. The visitors also learn about other local habitats, ecosystem uses and threats, and interact with the other 
youth involved in the program. They also engage in a cultural exchange of sorts where the visitors conduct an activity with local youth such as art and craft, composting etc. No money is exchanged for any of these services, but the visiting group offers tokens of appreciation to the youth that guide them and occasionally sponsor items such as refreshments, sports equipment, books etc. They bear all costs incurred by the visiting group.

\section{Visitor Feedback}

At the end of the last visit by a Kuala Lumpur-based bank, a feedback form was given to the visitors. Of 18 visitors, five were children, and ten forms were returned (couples tended to submit one form between them). The first question asked if the visitor had ever been to a seagrass meadow. Questions 2-4 asked about their guide's abilities; questions 5-7 tested their resultant knowledge of the seagrass meadow, the surrounds and seagrass conservation. Question 8 asked which part of their visit was most interesting to them, and question 9 asked if they would recommend the trip to friends and family. Question 10 asked for general comments and feedback. A sample of the feedback form and a summary of the responses are in the Appendix.

Nine of the ten visitors had never visited a seagrass meadow; one respondent left this question unanswered. All the visitors were able to understand their guide and felt that their guide was able to answer their questions and were able to identify flora and fauna successfully. All of the visitors were able to get at least three out of the five points correct for questions 5-7. Three were able to get all five points correct. This indicated a $100 \%$ pass rate for the knowledge questions. All the respondents listed the ability to see or experience flora and fauna (especially the seahorse) as the most interesting part of the trip and all were willing to recommend the visit to their friends or family.

Only six respondents wrote comments for question 10; three commended and thanked the youth guides for a job well done, one requested more information prior to the trip, one suggested that the youth continue to further their knowledge and monitoring work, as well as to engage with those in authority to push for protection of the area and the last simply wrote "love the environment".

Informal interviews with the guides after the event indicated that the youth thoroughly enjoyed themselves and were brimming with pride at being able to find and explain flora and fauna for their guests. They were especially amazed at how excited the guests were at being shown critters and plants that they had gotten used to seeing. Their ability to show visitors from the city things that were new and amazing to them seemed to make the youth visibly expand with pride. All were keen to guide again.

\section{Discussion}

The example detailed above is a small sample of just one visit and only a few guides, but it is a positive indication of the potential of this project and marine tourism in this area. The program is still in its infancy; more guides for all the local habitat need to be trained and put to the task; more visits need to be organised, and 
further environmental education needs to be implemented. The program is scheduled to run for another year before it is properly evaluated for success or failure.

At this point, however, it is clear that there is an interest in natural ecotourism in this area. The bank in question has already arranged to bring another 30-40 people to Mukim Tanjung Kupang in October 2010. It also seems that the youth involved in the program are fully capable of guiding and have increased in self-esteem since garnering guiding experience. Furthermore, the youth have also shown a change in attitude towards the environment.

Theory sessions on marine debris and the problems of improperly disposed of waste, coupled with sessions cleaning up local coastal areas and exposure to a completely damaged area after a recent pollution event were reinforced by the appreciation shown by visitors of their natural areas. The youth have now taken to informing each other, their elders and complete strangers (in no uncertain terms) not to litter or pollute their rivers and jetties. These are but small steps, but positive indications of progress and the potential of positive marine tourism in this area.

\section{Why Youth}

All discussions prior to this have indicated the need for local community education, but no specific mention has yet been made of youth being trained as guides. Howe (2001) states that participation by local communities can involve everyone; individuals, adults, schools, women etc. Cukier (2006) mentions that tourism employment can improve the quality of life and societal status as well as provide new opportunities for youth and women. This is especially so in areas with less formal education; the younger generation would find tourism employment much more appealing than the physical effort required of traditional sources of income such as fishing and agriculture.

The larger $\mathrm{PhD}$ research project that this program is a part of is focused explicitly on youth to assess their ability to disseminate information and influence peers and elders in the local community. Specific to the tourism aspect, these youth are meant to serve as a model to prove to others (especially village elders and local leaders) that small-scale tourism can be done in the mukim, with local guides.

While it is increasingly difficult for the local community to depend solely on traditional sources of income such as fishing, many are still unable to switch to other occupations or industries. Most are held back by an unwillingness to try something different from a tradition that has been their lifeline for generations, while others do not feel capable of moving to something else (Personal communication: Jum'at bin Haron, 2010). Only a handful has moved towards using their boats to send recreational fishermen to their desired fishing spot or for charter by universities and other organisations for research.

Should the program with these youth prove successful and if the local community can see for themselves that they are able to move into and get economic benefits from tourism, they might be inspired and motivated to give it a try. In the meantime, they are being fed by a steady but subtle stream of environmental information and local habitat knowledge through the youth. It is hoped that the by the time they are ready to leap ecotourism, they would have 
achieved some level of environmental sensitivity and empathy, allowing for proper sustainable tourism to take place, with a view to the long term conservation of their local habitats.

\section{Summary and Conclusion}

A group of 46 students of Mukim Tanjung Kupang are involved in an environmental education program that aims to increase their awareness and understanding of the local ecosystem and natural habitats. As part of that more comprehensive program, the youth are trained as Youth Rangers and guides. Depending on their age and ability, they take visitors to seagrass meadows, mangroves and the rocky shore. The program is still in its early stages, but brief feedback surveys given to one group of visitors have indicated an interest in nature-based tourism in this area and commended the youth and their guiding abilities. The feedback and post-guiding discussions with the youth themselves have shown that they have achieved an increased level of self-esteem and are keen to continue guiding.

Given the entrenched habits of the adults in this community and their reluctance to move to other forms of employment in spite of the increased difficulty in earning a living from traditional sources of income; these youth and their possibly successful ecotourism venture are meant to serve as a model to inspire others to do likewise. There is definite potential for sustainable marine ecotourism in this area, given the unique ecosystems in its vicinity. It is hoped that as a result of the efforts of the youth involved in this program, the wider community will be motivated and empowered to move to new alternative sources of income and a unique form of small-scale sustainable marine tourism can be further developed in this area.

\section{References}

Nurul Amin, S.M., Arshad, A., Ara, R., Daud, S.K., \& Mazlan, A.G. (2009). Abundance and temporal distribution of fish larvae in the seagrass bed of Sungai Pulai Estuary, Johore, Peninsular Malaysia. Presentation for the 8th Indo-Pacific Fish Conference and 2009 Australian Society for Fish Biology Workshop and Conference, 31 May - 5 June 2009.

Choo, C.K., Rahman, S., \& Khor, H.M. (2009). S.O.S. Files a journey to Sungai Pulai. Gelang Patah: Save our seahorses.

Christie, M.F., \& Mason, P.A. (2003). Transformative tour guiding: Training tour guides to be critically reflective practitioners. Journal of Ecotourism 2(1), $1-16$.

Coconut Village Resort (n.d.). Scuba diving @ Pulau Sibu/ Pulau Tinggi. Coconut Village Resort, Pulau Sibu. Retrieved September 15, 2010 from http://www.sibucoconutvillage.com/scuba-diving.html.

Cole, S. (2006). Information and empowerment: The keys to achieving sustainable tourism. Journal of Sustainable Tourism 14(6), 629-644. 
Cukier, J. (2006). Tourism employment issues in developing countries: Examples from Indonesia. In R. Sharpley \& D.J. Telfer (eds.), Tourism and development: Concepts and issues. New Delhi: Viva Books Private Limited, 2006.

Sea Gypsy Village Resort \& Dive Base Official Website (n.d.). Dan's nasty frogmen, dan's nasty divesites. Retrieved September 15, 2010 from http://www.siburesort.com/Dive\%20Base/Dive\%20Sites/Dan\%27s\%20Nas ty\%20Dive\%20Sites.htm.

Diamantis, D. (2004). Ecotourism: Management and assessment. London: Thomson Learning.

Eagles, P.F.J., McCool, S.F., \& Haynes, C.D. (2002). Sustainable tourism in protected areas: Guidelines for planning and management. Switzerland and Cambridge, UK: International Union for Conservation and Natural Resources.

Hall, C.M. (2001). Trends in ocean and coastal tourism: The end of the last frontier? Ocean \& Coastal Management 44, 601-618.

Howe, V. (2001). Local community training and education in Southern Tanzania A case study. Marine Policy, 25, 445-455.

Jacobson, S.K., \& Robles, R. (1992). Ecotourism, sustainable development, and conservation education: Development of a tour guide training program in Tortuguero, Costa Rica. Environmental Management 16(6), 701-713.

Japar, S.B., Zakaria, M.H., \& Arshad, A. (2006). Distribution and significance of seagrass ecosystems in Malaysia. Aquatic Ecosystem Health \& Management, 9(2), 203-214.

Jensen, O. (2010). Social mediation in remote developing world tourism locations -The significance of social ties between local guides and host communities in sustainable tourism development. Journal of Sustainable Tourism 18(5), 615-633.

Kibicho, W. (2008). Community-based Tourism: A factor-cluster segmentation approach. Journal of Sustainable Tourism 16(2), 211-221.

Luck, M. (2003). Education on marine mammal tourist as agent for conservation But do tourists want to be educated? Ocean \& Coastal Management, 46, 943-956.

Marine Park Department (n.d.). Total of visitors in Marine Park from year 2000 to year 2009. Department of Marine Park Malaysia. Retrieved September 15, 2010 from http://www.dmpm.nre.gov.my/84-visitors_data.html.

Mbaiwa, J.E. \& Stronza, A.L. (2010). The effects of tourism development on rural livelihoods in the Okavango Delta, Botswana. Journal of Sustainable Tourism 18(5), 635-656.

McNeely, J.A. (2005). Friends for life - New partners in support of protected areas. Gland: IUCN.

Nepal, S.J. (2004). Indigenous ecotourism in Central British Columbia: The potential for building capacity in the Tl'azt'en nations territories. Journal of Ecotourism, 3(3), 173-194.

Newsome, D., Moore, S.A. \& Dowling, R.K. (2006). Aspects of tourism: Natural area tourism (First Indian Ed.). New Delhi: Viva Books Private Limited. 
Okazaki, E. (2008). A community-based tourism model: Its conception and use. Journal of Sustainable Tourism, 16(5), 511-529.

Pipinos, G., \& Fokiali, P. (2007). An assessment of the attitudes of the inhabitants of Northern Karpathos, Greece: Towards a framework for ecotourism development in environmentally sensitive areas: An ecotourism framework in environmentally sensitive areas. Environment, Development and Sustainability, 11(3), 655-675.

RAMSAR (year). The annotated RAMSAR List: Malaysia. The RAMSAR convention on wetlands. Retrieved September 15, 2010 from, http://www.ramsar.org/cda/en/ramsar-pubs-annolist-annotated-ramsar16529/main/ramsar/1-30 168\%5E16529_4000_0__.

Sasekumar, A., Leh, C.M.U., Chong, V.C., Rebecca, D., \& Audery, M.L. (2006). The Sungai Pulai (Johore): A unique mangrove estuary. In: S.M. Phang, A. Sasekumar, S. Vickineswary (eds.), Malaysian society of marine science, (pp. 191-211). Universiti Malaya Kuala Lumpur.

Save Our Seahorses. (n.d.). Volunteers program. Save our seahorses Malaysia.

Retrieved September 15, 2010 from http://www.sosmalaysia.org/volunteers_program.html.

Stem, C.J., Lassoie, J.P., Lee, D.R., Deshler, D.D., \& Schelhas, J.W. (2003). Community participation in ecotourism benefits: The link to conservation practices and perspectives. Society \& Natural Resources 16(5), 387-413.

Timothy, D.J. (2006). Tourism and community development issues. In R. Sharpley \& D.J. Telfer (eds.), Tourism and development: Concepts and issues. New Delhi: Viva Books Private Limited.

Tourism Johor. (n.d.). Tanjung Piai-Johor national park. Tourism Malaysia official website. $\quad$ Retrieved September 15, 2010 from http://www.tourismjohor.com/destination/view.cfm?ID=C7E3D44CDF22-48F9 8EAE88AD83B1730E.

Tourism Malaysia. (n.d.). Tourism arrivals and receipts in Malaysia. Tourism Malaysia research. Retrieved September 2015, 2010 from http://www.tourism.gov.my/corportate/research.asp?page=facts_figures.

Tourism Malaysia (n.d.). Tanjung Piai National Park. Tourism Malaysia Destinations. $\quad$ Retrieved September 15, 2010 from http://www.tourism.gov.my/en/destinations/item.asp?item=tanjungpiai.

Walter, P. (2009). Local knowledge and adult learning in environmental adult education: Community based ecotourism in Southern Thailand. International Journal of Lifelong Education, 28(4), 513-532.

Wetlands International. (n.d.). RAMSAR sites in Malaysia. Wetlands international: Wetlands for water and life. Retrieved September 15, 2010 from

http://www.wetlands.org/Whatwedo/Ourfieldprojects/Projectarchive/tabid/ 59/ArticleType/ArticleVi w/ArticleId/128/Ramsar-sites-in-Malaysia.aspx.

Wilson, J.C., \& Garrod, B. (2003). Introduction. In B. Garrod \& J.C. Wilson (eds.), Marine ecotourism: Issues and experiences (1st ed.). England: Channel View Publications. 
Zaleha, K., Farah Diyana, M., Amira Suhaili, R., \& Amirudin, A. (2009). Benthic community of the Sungai Pulai Seagrass Bed, Malaysia. Malaysian Journal of Science, 28(2), 143-159.

\section{Interview}

i)Jum'at bin Haron, former fisherman and local leader, Kampung Pekajang, Mukim Tanjung Kupang. ii)Shalan bin Jum'at, boatman, Jeti Pak Ngah, Mukim Tanjung Kupang.

iii)Jum'at bin Haron, former fisherman and local leader, Kampung Pekajang, Mukim Tanjung Kupang

\section{Appendix: Seagrass Meadow Visit Feedback Form}

\begin{tabular}{|c|c|c|c|c|c|}
\hline No. & Question & \multicolumn{2}{|c|}{$\begin{array}{l}\text { Closed-ended questions: } \\
\text { responses }\end{array}$} & \multicolumn{2}{|c|}{ Open-ended questions: summary of responses } \\
\hline & Please write the name of your guide. & & & & \\
\hline 1 & $\begin{array}{l}\text { Have you ever been to a seagrass } \\
\text { meadow before? }\end{array}$ & $\begin{array}{l}\text { Yes } \\
\text { No } \\
\text { Blank }\end{array}$ & $\begin{array}{l}0 \\
9 \\
1\end{array}$ & & \\
\hline 2 & $\begin{array}{l}\text { Were you able to understand your } \\
\text { guide? }\end{array}$ & $\begin{array}{l}\text { Yes } \\
\text { No } \\
\text { Sometimes }\end{array}$ & $\begin{array}{l}10 \\
0 \\
0\end{array}$ & & \\
\hline 3 & $\begin{array}{l}\text { Was your guide able to answer your } \\
\text { questions? }\end{array}$ & $\begin{array}{l}\text { Yes } \\
\text { No } \\
\text { Sometimes }\end{array}$ & $\begin{array}{l}10 \\
0 \\
0\end{array}$ & & \\
\hline 4 & $\begin{array}{l}\text { Was your guide able to identify flora } \\
\text { and fauna? }\end{array}$ & $\begin{array}{l}\text { Yes } \\
\text { No } \\
\text { Sometimes }\end{array}$ & $\begin{array}{l}10 \\
0 \\
0\end{array}$ & & \\
\hline 5 & $\begin{array}{l}\text { List } 2 \text { facts that you learnt about the } \\
\text { seagrass ecosystem (or flora \& fauna). }\end{array}$ & & & $\begin{array}{l}\text { one correct answer }-7 \\
\text { two correct answers }-3\end{array}$ & $\begin{array}{l}\text { Summary of knowledge } \\
\text { question responses: }\end{array}$ \\
\hline 6 & $\begin{array}{l}\text { List } 2 \text { points that you learnt about this } \\
\text { area. }\end{array}$ & & & $\begin{array}{l}\text { one correct answer }-4 \\
\text { two correct answers }-6\end{array}$ & $\begin{array}{l}\text { three (out of five) correct } \\
\text { points }-3\end{array}$ \\
\hline 7 & $\begin{array}{l}\text { List } 1 \text { thing that you can do to help } \\
\text { conserve the seagrass ecosystem. }\end{array}$ & & & $\begin{array}{l}\text { no correct answers }-0 \\
\text { one correct answer }-1\end{array}$ & $\begin{array}{l}\text { four (out of five) correct } \\
\text { points }-4 \\
\text { five (out of five) points } \\
\text { correct }-3 \\
\qquad=100 \% \text { pass rate }\end{array}$ \\
\hline 8 & $\begin{array}{l}\text { What was the most interesting part of } \\
\text { your visit to the seagrass meadow? }\end{array}$ & & & $\begin{array}{l}\text { seahorse }-3 \\
\text { seahorse \& seagrass flora } \\
\text { seahorse \& other unique } \\
\text { sea creatures }-1 \\
\text { different seagrass flowers } \\
\text { "exposure: never seen, he }\end{array}$ & involved in before" -1 \\
\hline 9 & $\begin{array}{l}\text { Would you recommend this visit to } \\
\text { your friends or family? }\end{array}$ & $\begin{array}{l}\text { Yes } \\
\text { No }\end{array}$ & $\begin{array}{l}10 \\
0\end{array}$ & & \\
\hline 10 & $\begin{array}{l}\text { Please write any comments/ feedback } \\
\text { that you might have on your visit to } \\
\text { the seagrass meadow, Kelab Alami* } \\
\text { or your guide. }\end{array}$ & & & $\begin{array}{l}\text { unanswered }-4 \\
\text { thanks and commendatio } \\
\text { request for more informa } \\
\text { "increase guide's knowle } \\
\text { negotiation with the reley } \\
\text { constant monitoring and } \\
\text { protection ministry, for tl } \\
\text { "Love the environment". }\end{array}$ & $\begin{array}{l}\text { youth guides }-3 \\
\text { or to the trip }-1 \\
\text { ganise experts' talks/ } \\
\text { ironment authorities/ provide } \\
\text { h results to environment } \\
\text { take action" - } 1\end{array}$ \\
\hline
\end{tabular}

* Kelab Alami is the name of the locally-lead organisation created to teach local youth about the environment and train them as guides

Total feedback forms given: 13 Number of forms returned: 1 